TEME, г. XLIII, бр. 3, јул - септембар 2019, стр. 839-859

Прегледни рад

https://doi.org/10.22190/TEME171213051A

Примљено: 13. 12. 2017.

UDK 316.774:314.15

Ревидирана верзија: 19. 2. 2019.

Одобрено за штампу: 20. 10. 2019.

\title{
МИГРАНТСКА И ИЗБЕГЛИЧКА КРИЗА: КОМПАРАТИВНИ ПРИКАЗ ИЗВЕШТАВАЊА ДНЕВНИХ ЛИСТОВА БЛИЦ, ПОЛИТИКА И КУРИР
}

\author{
Душан Алексић ${ }^{*}$ Ивана Стаменковић \\ Универзитет у Нишу, Филозофски факутет, \\ Департман за комуникологију и новинарство, Ниш, Србија \\ *dusan.aleksic@filfak.ni.ac.rs
}

\begin{abstract}
Апстракт
Интензивне миграције током последњих година XX века и почетком XXI века важно су обележје савремених друштава, која постају мултикултурна. Док информације, идеје и људи непрестано прелазе државне границе, а појам нације застарева у новом комуникационом универзуму, темељи идентитета постају крхки, нестабилни и подложни променама. У кризним временима, медијско извештавање о групама које нису културално блиске домаћем становништву битно утиче на обликовање јавног мњења с обзиром на то да су непосредни контакти са таквим групама ограничени и ретки. Осим тога, поставља се питање колико се при таквом извештавању поштују етички кодекси. У овом раду анализирано је извештавање медија у Србији о мигрантској и избегличкој кризи у Европи. Предмет рада су првенствено медијске слике које се стварају о мигрантима и избеглицама кроз анализу неколико аспеката: заступљеност текстова о мигрантима и избеглицама, анализа жанрова, наслова, визуелне представе, поштовање новинарске етике, као и испитивање реторичких, стилских и манипулативних средстава који се користе. Анализирани су сви текстови о мигрантској и избегличкој кризи објављени у периоду од две недеље на три информативна веб-портала: Блиц, Курир и Политика. Прва анализирана недеља била је од 1. до 7. септембра 2015. године, док је друга анализирана недеља била од 1. до 7. марта 2017. године. Циљ ове компаративне анализе медијских текстова био је утврђивање евентуалних разлика у начину приказивања миграната и избеглица у медијским текстовима. Примарни циљ односи се на утврђивање разлике између три информативна портала у погледу истицања одређених аспеката кризе кроз коју пролазе мигранти/избеглице, као и у погледу наглашавања одређених карактеристика ове друштвене групе.
\end{abstract}

Кључне речи: миграције, мигранти, избеглице, медијска представа, медији, етика. 


\title{
MIGRANT AND REFUGEE CRISIS: COMPARATIVE ANALYSIS OF MEDIA REPORTING - CASE STUDY DAILY NEWSPAPER BLIC, POLITIKA AND KURIR
}

\begin{abstract}
Intensive migrations during the last years of the 20th century and in the beginning of the 21st century are an important part of modern societies which are becoming multicultural. While information, ideas and people cross countries' borders all the time, and term ,nation" is becoming outdated in new communication universe, the foundations of identity are becoming weak, unstable and subject to change. In crisis, media reporting about groups which are not culturally close to the native population significantly influences the public opinion creating, since direct contacts with such groups are limited and rare. Besides, the question arises to what extent such reporting is subject to the ethical codes.

In this paper, media reporting about recent European migrant and refugee crisis was analyzed. The paper is primarily focused on media representation of migrants and refugees which was analyzed through several aspects: frequency of texts about migrants and refugees, the analysis of genres, titles, visual presentation, respect of journalistic ethics as well as examination of rhetorical, stylistic and manipulative means that were used. All texts about migrant and refugee crisis published over a period of two weeks on three informative web-portals - „Blic“, „Kurir“ and „Politika“ were analyzed. The first analyzed week was from June 1st to September 7th, 2015, while the second week was from March 1st to March 7th, 2017. The goal of this comparative analysis of media texts was to determine possible differences in the way migrants and refugees are portrayed in media texts. The main goal was to determine diferences between three informative portals in terms of emphasis certain aspects of migrant and refugee crisis as well as in terms of emphasis certain characteristics of this social group.
\end{abstract}

Key words: migrations, migrants, refugees, media representation, media, ethics.

УВОД

Живот у савременом друштву намеће непрестано преиспитивање сопствених идентитета и позиција које заузимамо, као и потребу да промишљамо о другим културама и другачијим друштвима. Извора информација за такав подухват је све више, али је критичност у односу на медијски произведене садржаје све слабија. Док критичка моћ савременог човека опада пред пажљиво упакованим медијским производима, политичка и економска елита изнова потврђује своју важну улогу у управљању симболичким универзумом. Значења која медији генеришу о различитим групама јавност прихвата и на основу њих формира ставове и мишљење, моделе понашања и осећања. Уколико је реч о групи чије се културно наслеђе битно разликује од матрице домицилног становништва, наративне конструкције унутар медијског дискурса постају посебно важне. Какав ће став јавност заузети према одређеној групи - у највећој мери зависи од начина на који медији извештавају о њој.

На конструкционистичку природу медија указали су многи теоретичари (Gamson et al, 1992; Hall, 1997) објашњавајући како љу- 
ди користе медијски генерисане слике да би осмислили политичке и друштвене догађаје. Тежњи медија да створе слику света по властитој мери, али и мери њихових политичко-економских партнера, у умреженом друштву придружује се све већа количина информација и све флуиднији карактер категорија које до скоро нису биле доведене у питање. Непрестана интеракција вредности, уверења, идеја и афеката може довести до духовног богатства, али медијска пракса показује супротни тренд, који доводи до јачања негативних представа, предрасуда и стереотипа у приказивању припадника одређених друштвених група. Циљ скривених идеолошких порука у медијском пољу јесте усмеравање јавног мњења у правцу жељених реакција, као и добијање сагласности за одређене одлуке и јавно деловање.

Анализа медијске слике о мигрантској и избегличкој кризи треба да покаже колико се медијског простора посвећује том проблему, кроз какве форме и жанрове је представљен проблем мигрантске и избегличке кризе, те на која се реторичка, стилска и манипулативна средства ослањају те репрезентације. Једно од важних питања тиче се и поштовања постулата новинарске етике.

Жанрови у којима се обрађују питања и проблеми у вези са мигрантском и избегличком кризом говоре нам о томе како медији схватају овај савремени феномен и како се према њему постављају, што битно утиче на перцепцију и менталне моделе публике. Наслови су кључни у придобијању пажње аудиторијума (Јевтовић и други, 2014) и зато је анализа структуре насловног блока са наднасловом и лидом почетни корак, али и најважнији извор информација о представама стварности. Визуелни оквири (Goffman, 1974) постали су доминантна медијска стратегија утицања на афективне, али и мисаоне обрасце публике. Информативно кадрирање, кроз тематско рангирање, простор који одређена тема добија и жанровски избор, као и визуелно кадрирање - пружају значајан материјал на основу кога публика може да осмисли друштвену стварност.

Предмет овог рада је испитивање начина на који се о мигрантској и избегличкој кризи ${ }^{1}$ извештава на онлајн информативним порталима у Србији. Примена методе анализе садржаја о мигрантској и избегличкој кризи три информативна портала у Србији Блиц, Курир и Политика - има за циљ да открије које моделе представљања користи озбиљна, квалитетна штампа, насупрот таблоидној. Примарни циљ односи се на утврђивање разлике између три информативна портала у погледу истицања одређених аспеката кризе кроз коју пролазе мигранти/избеглице, као и у погледу наглашавања одређених

\footnotetext{
${ }^{1}$ У овом раду узета су у обзир екстерно расељена лица, односно, маркирани су новински текстови који говоре о мигрантима, избеглицама и азилантима.
} 
карактеристика ове друштвене групе. Такође, један од циљева је и утврђивање евентуалних разлика у начину приказивања миграната и избеглица у медијским текстовима објављеним на поменутим порталима у Србији током узоркованог периода у 2015. и 2017. години.

\section{ТЕОРИЈСКИ ПРИСТУП}

Традиционалним и новим медијима су на располагању многобројне стратегије у управљању јавним мњењем и стварању пожељних утисака. Док је у ери апсолутне доминације традиционалних масовних медија једносмерни комуникацијски процес подразумевао ширење порука и утицаја из центра моћи ка периферији друштва, данас се велики број агенаса укључује у процес формирања јавног мњења са тенденцијом настанка супротстављених погледа на друштвене појаве и свет. Ипак, чини се да није умањена снага централизујућих масовних медија у комуникацијски умреженом друштву, већ они, селећи своје садржаје у виртуелни простор, до крајњих граница користе потенцијале нових медијских платформи како би публици послали жељену конструкцију стварности. Тиме заправо желе да успостављени поглед на свет учврсте освајајући пажњу корисника нових медија који, у покушају стварања алтернативне перспективе, све више вреднују нове изворе информација. Медији су важна карика у комуникацијском ланцу не само као промотери идеологије друштвене елите већ и као стимулатори начина на који ће дебата о важним питањима бити прихваћена и интерпретирана. Социјални конструкционизам, као важан културалистички приступ, износи идеју да не постоји објективна стварност, већ културалне конструкције битно одређују начине на које ће појаве стварности бити именоване, дефинисане, протумачене и осмишљене. Праксом означавања баве се и медији будући да су важна институција која се ослања на обрасце културе у симболичкој продукцији стварности.

\footnotetext{
„Masovni mediji su infrastruktura za formiranje različitih govora o društvu. Oni obezbeđuju javnu komunikaciju i omogućavaju različitim akterima da se pozicioniraju prema raspoloživim simboličkim resursima. Zbog toga i mogu da se pojave kao institucionalni elementi selekcije u procesu označavanja. Ta selekcija jeste ideološki proces, ne u sadržajnom nego u strukturnom smislu, jer od uspostavljenih pravila koja važe za označavajuću praksu zavisi i kasnija 'proizvodnja značenja'. Zato je borba oko masovnih medija sukob oko simboličke produkcije, odnosno, sukob oko uslova pod kojima se u njoj učestvuje." (Milivojević, 2015: 27)
}

Поред теорије успостављања дневног реда (енгл. agenda setting), којој је темељ поставио још Волтер Липман (Walter Lippman) у првој половини XX века (Lipman, 1995), и теорије „чувара капија” (енгл. 
gatekeeping), теорија оквира (енгл. framing theory) представља важан приступ проучавању медијских садржаја и њихових ефеката.

Обрада „сировог” медијског материјала пролази сложене процесе сакупљања информација, њихове селекције и филтрирања, да би, потом, одређене теме постале део дневног „менија” медијске продукције стварности. Фабриковање фаворизованих медијских ефеката подразумева и - некад видљиво, некад латентно - смештање бујице слика, информација и утисака у одређене калупе или оквире. Поред фокуса у извештавању којим медији подешавају оптику аудиторијума, често се прибегава приказивању одређеног друштвеног проблема из специфичног угла, при чему информативни и визуелни стубови имају за циљ да елиминишу другачије погледе и да наметнути приступ представе јединим могућим. Дејвид Џајлс (David Giles) дефинише медијско уоквиравање као „процес путем ког медијски извор представља неку тему из одређеног угла, помоћу коришћења наслова, слика, заглавља, назива, језика који користи, извора које цитира и бројних других средстава" (Džajls, 2010: 218).

С обзиром на то да се оквири могу наћи свуда и да се примењују у свакодневном животу на различитим плановима, њихови извори налазе се у култури унутар које се конструишу медијске приче (Goffman, 1974; Entman, 1993; Van Gorp, 2007). Д’Анђело (D’Angelo, 2002) наглашава да су оквири важне јединице дискурса, док неки аутори напомињу да се доминантни оквири могу манифестовати посредством различитих дискурса (Reese и остали, 2008). Култура и симболичко окружење представљају извор оквира и спону која повезује медијске оквире са оквирима публике. Да би оно што се говори посредством медијских оквира било прихваћено у јавности и да би се успоставила веза између продукције и потрошње вести, треба се окренути заједничком симболичком наслеђу (Van Gorp, 2007). Према Ван Горпу, вести користе заједничке идеје једне културе, тако да оквири вести могу да изражавају симболички важне појмове попут стереотипа, вредности, архетипова, митова и наратива (Van Gorp, 2010: 85). Коришћење културно блиских образаца у медијском тексту за резултат има стварање разумљивих кодова који имплицитно утичу на перцепцију и интерпретацију поруке на полу прималаца (Van Gorp, 2010: 87). Ван Горп је, анализирајући како је дневна штампа у Британији представила азиланте, открио два доминантна оквира на која се ослањају медијске презентације: оквир жртве и оквир уљеза. Док Ван Горп први оквир повезује са архетипском улогом невине жртве, други оквир заснован је на стереотипном уверењу да су сви странци уљези (Van Gorp, 2005: 489). Он је дошао до резултата да у британској дневној штампи доминира приказивање азиланата кроз оквир жртве. 
У истраживању уоквиравања теме имиграције Румуна у оквиру британских квалитетних (The Guardian, The Independent) и таблоидних листова (Daily Mail), Череги (Cheregi) указује на битну разлику у тематизовању предмета истраживања. Док квалитетни листови нагласак стављају на економске последице до којих долази због доласка румунских имиграната који се медијски представљају као претња економском благостању, таблоиди пажњу усмеравају у правцу такозваних људских прича, а наративи често садрже теме као што су сиромаштво, криминал и пљачкање (Череги, 2015). Холмс (Seith M. Holmes) и Кастанеда (Heide Castaneda) приступају анализи медијске репрезентације европске избегличке кризе у Немачкој ослањајући се на концепт Антонија Грамшија „рат за позицију” (енгл. war of position), односно борбу за доминацију одређеног погледа на свет. Они су се у свом раду усредсредили на борбу са значењем, легитимизацијом и моћи која учествује у конструисању мигрантске и избегличке кризе, али и позиционира мигранте и избеглице унутар друштва у које се усељавају. Водеће место у процесу симболичкокомуникацијске конструкције стварности припада медијским извештавањима, изјавама политичара и популарном дискурсу. Ово симболичко надметање може да води у озакоњење и јачање политичкоекономских структура, али и да их оспори и да им пружи отпор у одређеним тренуцима. Динамичне релације у сфери политике и економије одражавају се на ставове домицилног становништва према људима који доспевају до граница њихове државе, што може имати као последицу интегрисање људи који долазе или њихову социјалну изолацију и искључивање. Дискурзивни оквири који се користе у медијским репрезентацијама, али и политичким и популарним наративима, откривају како се распоређује одговорност за патњу миграната и избеглица, како се мобилише страх од културних, етничких и верских разлика, те како се групишу они који долазе у категорију преступника који ништа не заслужују, при чему се они стигматизују и обележавају као економски „опортунисти”, и групу људи којима држава треба да помогне и који су достојни пријема. Преузимање контроле над конструкцијом оквира и значења у јавном дискурсу, чак и ако се превазиђу поделе на људе достојне пријема и оне недостојне, према којима је, имплицитно или експлицитно дозвољено испољити ксенофобију - подразумева да ће друштвени, политички и економски систем и даље одлучивати о будућности тих људи, о томе ко ће живети, а ко не (Holmes and Castaneda, 2016). Проучавајући наратив дневних листова у Великој Британији, Француској и Италији у вези са имиграцијама, Кавидес (Alexander Caviedes) уочава да су доминантна два оквира, економски и безбедносни. Оба имају негативну конотацију - док се први доводи у везу са динамиком на тржишту рада и трошковима додељивања азила, безбедносни оквир односи се 
на избеглице као физичку претњу, доводи их у везу са тероризмом и криминалом, те са границама које се прелазе легално или илегално (Caviedes, 2015).

\section{МЕТОДОЛОШКИ ОКВИР}

Савремене друштвене околности учиниле су да миграције и мигранти постану популарна и важна тема у медијском дискурсу. Медијски обликоване информације о мигрантској кризи и избеглицама генеришу став јавности у складу са владајућим друштвеним дискурсом. Предмет рада је представљање мигрантске и избегличке кризе на изабраним информативним порталима Србије. Циљ овог истраживања јесте уочавање и анализа начина и форми приказивања овог важног друштвеног феномена.

Такође, циљ је да поређењем веб-сајтова три дневна листа Блии, Политика и Курир уочимо да ли постоји тенденција ка сензационалистичком извештавању у озбиљној, квалитетној штампи и таблоидним медијима, односно да ли постоји разлика међу овим медијским форматима.

\section{Узорак истраживања}

Јединица анализе је новински текст на порталу поменута три медија, при чему су узети у обзир: датум објављивања текста, жанр, наслов (наднаслов и лид), стилска и реторичка средства која су коришћена у тексту и визуелне представе, уз посебан осврт на поштовање новинарске етике.

Анализирани су текстови о мигрантској и избегличкој кризи објављени на три информативна веб-портала: Блии, Курир и Политика. Истраживањем су обухваћена два периода: од 1. септембра до 7. септембра 2015. године и од 1. марта до 7. марта 2017. године.

За анализу је коришћен метод квантитативно-квалитативне анализе садржаја. Квантитативном анализом открићемо у којој мери се извештава о мигрантској и избегличкој кризи, односно, који медијски простор добија ова тема. Квалитативна анализа треба да покаже на који се начин представљају мигрантска и избегличка криза и која се значења стварају о њој на изабраним информативним порталима. У делу квалитативне анализе биће, пре свега, узети у обзир наслови новинских текстова, с обзиром на то да су они конструисани као „мамац” за читаоце и у том погледу су посебно информативни кад је реч о представама стварности. Такође, биће указано и на шири контекст политичких, економских и друштвених околности Србије који уобличавају извештавање о мигрантској/избегличкој кризи. 


\section{РЕЗУЛТАТИ ИСТРАЖИВАЬА И ДИСКУСИЈА}

У анализираним периодима пронађено је укупно 498 текстова на сва три веб-портала чија тема је директно или индиректно везана за мигрантску кризу. Под текстовима проблематичне етичности у овом раду подразумевамо оне у којима су мигранти обележени као претња по безбедност државе, економску стабилност, културу, њен вредносни и здравствени систем, односно текстови у којима постоји корелација између извештавања о мигрантима и употребе стереотипа $^{2}$. Број текстова класификованих према порталима и времену објављивања приказан је у Табели 1.

Табела 1. Поређење броја објављених текстова и текстова проблематичне етичности у анализираним дневним листовима

\begin{tabular}{|c|c|c|c|c|c|c|}
\hline $\begin{array}{l}\text { Дневни } \\
\text { лист }\end{array}$ & $\begin{array}{c}\text { Укупно } \\
\text { текстова- } \\
\text { септембар } \\
2015 .\end{array}$ & $\begin{array}{c}\text { Текстови } \\
\text { проблема- } \\
\text { тичне } \\
\text { етичности - } \\
\text { септембар } \\
2015 .\end{array}$ & $\begin{array}{c}\text { Укупно } \\
\text { текстова } \\
\text { - март } \\
2017 .\end{array}$ & $\begin{array}{c}\text { Текстови } \\
\text { проблема- } \\
\text { тичне } \\
\text { етичности - } \\
\text { март } 2017 .\end{array}$ & $\begin{array}{c}\text { Укупно } \\
\text { текстова }\end{array}$ & $\begin{array}{c}\text { Укупно } \\
\text { текстова } \\
\text { пробле- } \\
\text { матичне } \\
\text { етичности }\end{array}$ \\
\hline$\overline{\text { Блиц }}$ & 328 & 123 & 22 & 12 & 350 & 135 \\
\hline Политика & 29 & 16 & 0 & 0 & 29 & 16 \\
\hline Курир & 115 & 77 & 3 & 3 & 118 & 80 \\
\hline
\end{tabular}

На основу квантитативне анализе, јасно је да је мигрантска криза најзаступљенија на онлајн порталу Блиц. Од 498 анализираних текстова, 328 објављено је на овом медију. Иако је за Блиц ово била тема од велике важности у првом анализираном периоду, интересовање за њу опало је током марта 2017. године, као што је то случај и са преостала два медија. Дневни лист Политика у онлајн верзији дао је најмање простора овој теми, али је и већи проценат текстова био проблематичне етичности. Осим тога, треба нагласити да једино Политика није посветила ниједан текст мигрантској/избегличкој кризи током анализе у марту 2017. године. Иако је Курир овој теми посветио значајан број текстова у 2015. години, тај број је далеко мањи у поређењу са Блищом. И у овом случају приметно је драстично смање-

\footnotetext{
${ }^{2}$ Наслови су довољно индикативни кад је реч о проблематичности медијске представе мигрантске/избегличке кризе: „ШОКАНТНА ИСПОВЕСТ БРИТАНСКЕ НОВИНАРКЕ[:] 'Мигранти у Шведској СИЛУЈУ и пљачкају, а нико НЕ СМЕ ДА ЗУЦНЕ”” (2. март 2017); „Орбан: избеглице прете хришћанским коренима Европе” (3. септембар 2015), „ПОНОВО ХАОС[:] Мигранти окупирали 'Келети', полиција се повлачи - а возови стоје” (3. септембар 2015), „Штампа: Немачку ће избеглице коштати 10 милијарди евра" (5. септембар 2015).
} 
ње интересовања у марту 2017, али је занимљиво да су сва три објављена текста била проблематичне етичности.

У савременом свету све друштвене сфере посредују се медијима (Livingstone, 2009), а савез између медија и политике чини се да је још јачи, при чему се механизми политичког маркетинга у медијима непрестано усавршавају, што се може уочити пажљивом анализом медијског садржаја. Фокус извештавања медија мења се током времена, а свака промена теме и наратива сведочи о промени става владајућег слоја и значајних актера комуникацијског процеса према друштвеном проблему. Маргинализација проблема или драстично смањење медијског простора за одређени друштвени проблем, појаву или феномен шаљу поруку публици да би требало мање да размишља о њему, будући да је тема изгубила на значају, или говори о фингираним покушајима да се проблем замаскира, односно да се његово постојање негира, како би се одређене политичке одлуке спровеле изван простора јавне сцене. У супротном случају, фаворизација одређене теме у медијима и интензивно извештавање о њој има сврху скретања пажње са важнијих друштвених проблема чије се решавање одвија иза медијских кулиса, изван домета пажње јавности.

Суочени са све сложенијим друштвеним окружењем које је у великом степену медијатизовано и загађено „прашином” медијских порука, сваки облик поједностављивања стварности и његових категорија прихвата се без критичког осврта. Отуда су стереотипи одувек били присутни у медијском дискурсу, а њихово повезивање са спектакуларним и сензационалним приступом у формирању медијских представа показује се као сигурна формула успеха на тржишту. Међутим, медијско промовисање и апострофирање слика и ставова заснованих на стереотипима и предрасудама указује на сужавање когнитивног поља обраде медијских порука о одређеним личностима, друштвеној групи или појави, уз призивање афективних одговора публике. Тренд извештавања који се очитава кроз фаворизацију теме, а потом драстично смањење интензитета извештавања, као и присуство проблематичне димензије у осликавању мигрантске кризе и миграната - у складу је са идејама и стратешким плановима владајуће елите. Идеолошко обликовање медијске продукције примарни је предмет истраживачке делатности присталица студија културе, а интересовање за препознавање медијских садржаја у којима се спроводи репродуковање доминантне идеологије и данас је значајно. 
Табела 2. Жанровска заступљеност

\begin{tabular}{|c|c|c|c|c|c|c|c|c|c|c|c|c|c|c|c|}
\hline \multirow[t]{2}{*}{ Лист } & ర్ & & 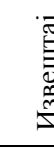 & & 焉 & & 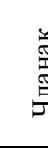 & & 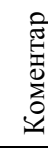 & & 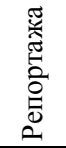 & & 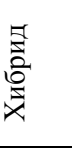 & 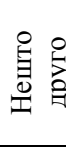 & 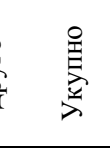 \\
\hline & $\dot{\tilde{U}}$ & & $\dot{\Xi}$ & $\sum_{i}^{\frac{5}{2}}$ & 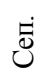 & 淧 & $\dot{0}$ & 窎 & ن் & 亳 & $\dot{\vec{U}}$ & : & 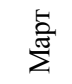 & 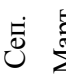 & 这 \\
\hline Блиц & 99 & & 195 & 10 & 4 & 0 & 13 & 1 & 0 & 0 & $\begin{array}{ll}0 & 1\end{array}$ & 117 & 1 & 0 & $\begin{array}{llll}0 & 328 & 2\end{array}$ \\
\hline Политика & 2 & 0 & 13 & 0 & 2 & 0 & 1 & 0 & 5 & 0 & 0 & $0 \quad 5$ & 0 & $1^{3}$ & $0 \quad 29$ \\
\hline Курир & 12 & 1 & 67 & 2 & 0 & 0 & 1 & 0 & 2 & 0 & $0 \quad 0$ & $\begin{array}{lll}0 & 33 \\
\end{array}$ & 30 & 0 & $\begin{array}{lll}0 & 115\end{array}$ \\
\hline
\end{tabular}

Када је реч о жанровској заступљености, сва три портала су у највећој мери о мигрантској кризи извештавала кроз класичне информативне жанрове - вест и извештај, док је аналитичких и белетристичких жанрова занемарљиво мало. То нам показује да су се ова три узоркована медија најчешће бавила последицама, а не узроцима мигрантске кризе, односно да је изостала новинарска анализа дешавања која су месецима окупирала пажњу светске јавности. Осим информативних жанрова, у далеко мањем броју јавили су се хибридни жанрови који представљају мешавину више жанрова или жанрове који не припадају ниједној класичној подели, а који су карактеристични за савремено новинарство, посебно за онлајн издања.

Доминација информативних жанрова, односно фактографије, означава одсуство дубље анализе проблема и указивање на могућа решења. Задржавање на информацији, на површини, без понирања у дубину проблема - подразумева да је читалац слободан да сам интерпретира медијски текст и да открива његово значење кроз понуђене елементе друштвене стварности. Оно што се овде назире као проблем тиче се уплитања стереотипних елемената, кроз именовање и обележавање миграната, што се рефлектује на тумачење публике. Уколико се одређена друштвена дешавања не повежу са ширим контекстом, узроцима и последицама, и тиме се озбиљније приступи проблему миграција, читалац ће добити фрагментарно сазнање на основу којег ће формирати одређену, углавном искривљену, перцепцију друштвене реалности с обзиром на то да су контакти са мигрантима ограничени, а искуства и сазнања о њима посредна. Домаћи аутори проницљиво уочавају да се променом наратива у медијском дискурсу мења не само јавно мишљење о некој теми већ и свест аудиторијума (Јевтовић, Бајић, 2017). Одсуство аналитичког приступа и доминација сензационалистичког извештавања резултирали су конфузијом у ставовима грађана према проблематици мигрантског

\footnotetext{
${ }^{3}$ Увод у чланак који је у потпуности доступан у штампаном издању.
} 
питања, тврде Владимир Вулетић и његови сарадници у „Студији о избеглицама" (2016).

Табела 3. Визуелна презентација

\begin{tabular}{lcccccccccc}
\hline & Само текст & $\begin{array}{c}\text { Текст }+ \\
\text { фотографије }\end{array}$ & $\begin{array}{c}\text { Текст }+ \\
\text { видео }\end{array}$ & $\begin{array}{c}\text { Текст }+ \\
\text { више } \\
\text { категорија }\end{array}$ & Укупно \\
& Сеп. Март & Сеп. & Март & Сеп. Март & Сеп. Март & Сеп. Март \\
\cline { 2 - 9 } & 18 & 3 & 293 & 18 & 2 & 0 & 15 & 1 & 328 & 22 \\
Блии & 3 & 0 & 26 & 0 & 0 & 0 & 0 & 0 & 29 & 0 \\
Политика & 1 & 0 & 95 & 2 & 1 & 0 & 18 & 1 & 115 & 3 \\
\hline
\end{tabular}

У погледу визуелне представе, јасно је да су се ови медији у највећем броју случајева одлучили да текстове илуструју фотографијама. Иако им онлајн платформа дозвољава да користе више мултимедијалних елемената, попут видео-клипова, то овде није случај.

Савремено новинарство, нарочито таблоидног карактера, заснива се на фаворизовању инстант информација, слика, фотографија и видео-записа. Међу карактеристикама тзв. контекстуалног новинарства Џон Павлик (John Pavlik, 2001) наводи и мултимедијалност. Он истиче да редакције дневних листова ретко користе мултимедијалне могућности у представљању медијског материјала на сајтовима, и за то наводи три могућа разлога: недостатак ресурса, необученост запослених и непрепознавање значаја коришћења аудио и видео материјала.

Табела 4. Тип наслова

\begin{tabular}{lrrrrrrrr}
\hline Лист & \multicolumn{1}{c}{ Информативни Сензационалистички Метафорички } & \multicolumn{2}{c}{ Укупно } \\
\cline { 2 - 9 } & Сеп. & \multicolumn{1}{c}{ Март } & Сеп. & Март & Сеп. & Март & Сеп. Март \\
\hline Блиц & 218 & 11 & 77 & 9 & 33 & 2 & 328 & 22 \\
Политика & 14 & 0 & 4 & 0 & 11 & 0 & 29 & 0 \\
Курир & 39 & 1 & 66 & 2 & 10 & 0 & 115 & 3 \\
\hline
\end{tabular}

Када говоримо о насловима, на сајту Блица и Политике преовладали су наслови информативног типа. Ипак, Блии је имао и значајан број сензационалистичких наслова, што показује да се мигрантска криза користила за привлачење што већег броја читалаца, док се о етичким кодексима није водило рачуна. Овај резултат потврђује да се овај дневни лист све више профилише као таблоидно медијско средство. Број сензационалистичких наслова у односу на остале штампане листове био је највећи у Куриру, који је таблоид, а сензационалистички наслови једна су од карактеристика овакве врсте медија. На сајту листа Политика уочен је најмањи број сензационалистичких наслова, што чини значајну разлику између озбиљне и таблоидне штампе. 
На глобалној медијској „пијаци” данас се тргује садржајима који се одликују прожимањем забаве и информативе, а сваки „зачин” у виду сензације и спектакла осигурава наклоност публике и оглашивача. Земље у транзицији, попут Србије, представљају плодно тло за развој агресивног, нетолерантног и сензационалистичког новинарства, док истраживачко новинарство одумире. Залагања за либерализацију и дерегулацију тржишта доводе до угрожавања институције јавне расправе и разумног дијалога, истиче Роберт Мекчесни (Robert McChesney, 1999). Одсуство аналитике у медијској продукцији и медијској обради друштвених догађаја неминовно воде у једноличне репрезентације и једноумље јавног мњења. Промена професионалне оријентације и све јаснија наклоност сензационалистичком моделу извештавања уочљива је у редакцији дневног листа Блиц. То се огледа у занемаривању квалитета саопштења и истинитости информација, при чему се уредништво руководи макијавелистичким флоскулом да циљ оправдава средство, где се као циљ препознаје доминација на тржишту идеја.

Тржишна оријентација медија условила је, дакле, појаву сензационалистичког приступа у извештавању о мигрантској и избегличкој кризи. Контрола над конструкцијом значења и формирањем оквира у медијском дискурсу припада водећим актерима у политичком и медијском систему. Најчешће значењске категорије о мигрантима и мигрантској и избегличкој кризи које је могуће идентификовати у новинским текстовима - откривају да се мигранти могу перципирати као жртве и као претња. О представљању миграната кроз оквир жртве сведоче одабрани наслови са веб-сајта дневног листа Блищ: „Немачка: бибер-спрејом напао мигранте, више од 40 повређених” (Блии, 2. септембар 2015), „Докле ће свет гледати овакве призоре? ДЕЦА СЕ МОРАЈУ СПАСТИ” (Блии, 2. септембар, 2015), „СКАНДАЛ, словеначки новинар предлаже: Пуцати на избеглице!” (Блиц, 3. септембар, 2015), „БЕЗ МИЛОСТИ Отац и мајка с бебом легли на шине, на њих скочило 12 МАЂАРСКИХ ПОЛИЦАЈАЦА" (Блии, 3. септембар, 2015).

Поред усмеравања перцепције јавности према оквиру жртве, мигранти се често стигматизују као претња друштву на различитим плановима. Илегални улазак миграната, мигранти као финансијски терет државе, мигранти као претња националном и религијском идентитету, сукоби са полицијом и међусобни обрачуни међу мигрантима честе су теме у Блииу: „ВОЈСКА И БОДЉИКАВА ОГРАДА Орбан у Бриселу представио решење за избеглице” (3. септембар 2015), „Орбан: избеглице прете хришћанским коренима Европе” (3. септембар 2015), „ПОНОВО ХАОС Мигранти окупирали 'Келети', полиција се повлачи - а возови стоје” (3. септембар 2015), „Штампа: Немачку ће избеглице коштати 10 милијарди евра" (5. септембар 
2015), „Побуна миграната у Шпанији, полиција користила гумене метке, петоро повређених" (7. септембар 2015). Извештавање Блиияа о мигрантима у сензационалистичком маниру наставља се и у марту 2017. године. Иако опада интересовање за ту тему, овај дневни лист не мења стил информисања о миграторним кретањима. О томе сведоче неки од изабраних наслова: „МАЛИ ПИКАСО ИЗ МИГРАНТСКЕ КОЛОНЕ Фахрад (10) из Авганистана у кампу у Крњачи сапатнике одушевљава цртежима” (2. март 2017), „ШОКАНТНА ИСПОВЕСТ БРИТАНСКЕ НОВИНАРКЕ 'Мигранти у Шведској СИЛУЈУ и пљачкају, а нико НЕ СМЕ ДА ЗУЦНЕ”” (2. март 2017), „Хрватска: На карневалу запаљен 'Азилант', симбол свега лошег” (3. март 2017).

Медијски лидери су у сталној потрази за садржајима који ће привући ширу публику и остати у средишту њене пажње. Хипнотисана количином информација које одликује лош квалитет кројен према дневнополитичким интересима, публика постаје апатична. Под непрестаним „туширањем” информацијама, она је дезоријентисана, а њена способност одабира, вредновања и процене медијских садржаја драматично опада. На тај начин најмањи заједнички именитељ који представља спону између медијских форми и садржаја, с једне стране, и публике, на другој страни, поспешује кризу у расуђивању.

„U kakofoničnom mozaiku medijskih proizvoda svest teško pronalazi sigurne oslonce (uporišta). Uostalom, pitanje je da li je ona uopšte u stanju da apsorbuje broj informacija, mozaičnih i modifikovanih, odnosno stalno prilagođavanih temporalno, prostorno, situaciono, interesno..." (Jovanović, 2015: 295)

Пословна оријентација листа Курир нимало се не разликује од дневног листа Блиц, тржишног супарника и конкурента. Утицај сензација и присуство афеката у причама о мигрантима у Куриру посебно су изражени. На основу наслова можемо да закључимо да позивање на емпатију и афекат доминира, а ефекат је додатно појачан визуелним представама које стоје уз текст. Уочљиво је да се мигрантима, као и у Блииу, подједнако додељује улога жртве, али се они неретко обележавају и као уљези и претња. Неки од наслова сведоче о томе: „АМБАСАДОР ТРГОВАЦ ЉУДИМА: Од шверца избеглица узео 800.000 евра!” (1. септембар 2015), „НАЈСРДАЧНИЈИ ГРАД У ЕВРОПИ: Погледајте како су у Немачкој људи дочекали избеглице из Сирије” (1. септембар 2015), „(УЗНЕМИРУЈУЋЕ) СЛИКЕ КОЈЕ СУ ПОТРЕСЛЕ СВЕТ: Море избацило сиријског дечака (3) на плажу у Бодруму” (2. септембар 2015), „ШКОЛИЦА ЗА МАЛЕ МИГРАНТЕ: Вербић организује програме и радионице за децу избеглице" (3. септембар 2015). У текстовима, а поготово у насловима, примећује се велики број метафора и хипербола, које додатно драматизују тон извештавања о мигрантима и њиховим кретањима: „НОВИ 
ТАЛАС МИГРАНАТА: Македонци издали више од 2.000 потврда за 12 сати” (3. септембар 2015), „ХРЛЕ КА АУСТРИЈИ: Воз пун миграната кренуо из Будимпеште” (3. септембар 2015), „РАСУЛО У ЖЕЛЕЗНИЦИ: Мађарска укинула возове за Чешку и Немачку" (3. септембар 2015), „(ФОТО) ВЕЛИКИ МАРШ: Избеглице кренуле пешке у Беч из Будимпеште” (4. септембар 2015), „ОРБАН: Прилив избеглица је бесконачан, ми смо мањина на сопственом континенту” (4. септембар 2015), „ЕВРОПА ГРЦА, ОБАМА ЋУТИ: Сједињене Државе ће примити само 1.800 избеглица из Сирије!” (5. септембар 2015). Флуктуације у наративу о мигрантској и избегличкој кризи одраз су промене парцијалних интереса елите која управља свешћу и умом публике. Промена наратива у медијском дискурсу води промени јавног мњења и когнитивно-афективног одговора публике. Како примећују Вулетић и његови сарадници, сензационалистички начин уоквиравања информација о мигрантима изазива конфузију у ставовима грађана Србије. Забуну додатно појачавају супротстављени наративи у медијском дискурсу, истовремено присуство различитих медијских оквира, као и промена фокуса са једног медијског оквира на други.

Метод „топле људске приче” постаје фаворизовано средство медија које се уплиће у све врсте жанрова. Интима појединаца располаже „капиталом” који је све флуиднији и динамичнији у медијском дискурсу. Користећи енергију личне приче, медији увлаче публику у фантазмагорични свет где се више не постављају питања и не покрећу смислене друштвене акције, већ се публика предаје владавини осећања која инхибира рационалне одговоре. У прилог томе говоре следећи наслови дневног листа Курир: „(ВИДЕО) ОТАЦ НАСТРАДАЛЕ ДЕЦЕ КОЈА СУ РАСПЛАКАЛА СВЕТ: Само сУ мИ склизнули из руку, они су били најлепши на свету" (3. септембар 2015), „КОНОБАР КОЈИ ЈЕ ПРОНАШАО НЕСРЕЋНОГ ДЕЧАКА: Чинило се као да су живи, као да спавају насмејани!” (3. септембар 2015), „ОСТАО САМ НА СВЕТУ: Отац утопљеног сиријског дечака враћа се у Кобане” (4. септембар 2015), „ТАТА, НЕМОЈ ДА УМРЕШ, МОЛИМ ТЕ: Последње речи малог Ајлана пре него што га је из очевих руку истргао талас!” (5. септембар 2015), „ОНИ НЕ МОГУ ДА ОСТАНУ У КОБАНЕУ: Тетак утопљеног дечака бори се да породицу доведе у Канаду" (6. септембар 2015).

Иако је веома важно идентификовати емоције које покрећу сваку културу и важне су за друштвену динамику и међуљудске односе, медијска манипулација афектима остварује назадне циљеве. „Тежња да се прикаже људска драма, да се дају сензационалистички обриси вестима и да се речима и фотографијама дочарају и приближе осећања актера, делује привлачно и атрактивно публици. То доводи до пораста тиража, остваривања жељеног профита, али и до анестезирања публике која [ce], у процесу рецепције таквих порука, 
емоционално супротставља рационалном, дајући предност осећањима" (Стојковић, Петковић, 2015: 331).

Дневни лист Политика је мању пажњу посветио теми миграција, а када се и извештавало о томе, тон је био умерен и објективнији, али је и у овом листу заступљена одређена доза сензационализма и дискутабилно поштовање новинарске етике. Како је показала квантитативна анализа, од 29 анализираних текстова, у 16 су установљени елементи кршења новинарске етике у погледу критеријума наведених на почетку овог рада. У прилог томе говоре наслови попут: „Како ће Брисел бранити Шенген?” (2. септембар 2015), „Како је Ангела Меркел постала избегличка мајка" (3. септембар 2015), „Врисак немог тела” (4. септембар 2015), „Шта све можеш кад си у ЕУ” (4. септембар 2015). Међутим, треба нагласити да, иако не заостаје у визуелној репрезентацији догађаја, Политика дозирано снабдева публику фотографијама, односно, води рачуна да не изазове афективну преплављеност и шок код читалаца. Према насловима овог листа, тешко је одредити како се категоришу мигранти, односно, да ли постоје оквири у тексту и фотографијама који се сугеришу у интерпретативној обради информација. Судећи по фотографијама, може да се наслути присуство димензије хуманости и апел за помоћ мигрантима.

Компарација дневних листова из узорка, где Политика представља озбиљан дневни лист са најдужом традицијом у Србији, а $K y$ рир и Блиц се профилишу као таблоиди, показује неколико карактеристика по којима се разликују ови медијски формати. Политика је у узоркованом периоду, односно од 1. до 7. септембра 2015. године и од 1. до 7. марта 2017. године, објавила значајно мањи број текстова о мигрантској/избегличкој кризи него Блии и Курир (29 у односу на 350 и 118). У погледу поштовања етичке димензије у извештавању, Политика, међутим, бележи сличну тенденцију наклоности сензационалистичком обрасцу, по угледу на Блии и Курир (док је проценат таквих текстова у односу на укупан број текстова о мигрантској/избегличкој кризи у Блииу 38,5\%, у Куриру 67, 8\%, у Политищи је $55,2 \%)$. Међутим, према типу наслова, Политика предњачи у информативним насловима, а најмањи проценат наслова могуће је сврстати у сензационалистичку категорију (свега 13,8\%). Постоји сличност између озбиљне и таблоидне штампе у узорку у погледу жанровске обраде догађаја, јер су обе врсте медијског формата биле усредсређене на информативне жанрове (вест и извештај), док је занемарљив број аналитичких текстова који би обезбедили понирање у суштину и узроке проблема и контекстуално га лоцирале. Још једна разлика која се уочава између озбиљног листа Политика и његових таблоидних конкурената односи се на квалитет визуелне репрезентације мигрантске/избегличке кризе, тачније на начин представљања овог друштвеног пробле- 
ма. Док таблоиди срачунато користе људске емоције којима преплављују публику, често изазивајући шок и јаке афективне ракције, Политика не манипулише отворено афективним системом читалаца. Чак и када се код овог озбиљног листа и идентификује фотографија са снажним емоционалним набојем, њена сврха није гушење рационалне димензије одговора, већ управо освешћивање и буђење критичке свести шире јавности и националног, као и глобалног политичког естаблишмента.

Бавећи се анализом насловних страна већег корпуса дневних новина у Србији током 2015. и 2016. године, Јевтовић и Бајић дошли су до сличних запажања. Разлика између озбиљне штампе и таблоида и даље постоји и она се очитава у присуству две супротстављене врсте дискурса. У таблоидима се уочава „сензационалистички и ксенофобични дискурс заснован на страху од придошлица и тези о планској исламизацији Европе, док контранаратив форсира хуманитарну димензију катастрофе, бригу о другом и поштовање људских права" (Јевтовић, Бајић, 2016: 42).

Специфичан контекст Србије обликован историјским наслеђем и колективним искуствима значајно утиче на генерисање представе о мигрантима и избеглицама. Велика незапосленост, изражено сиромаштво и нестабилност у различитим сферама друштвеног живота предиспозиције су за стварање ксенофобије и анимозитета према странцима, односно, културно другачијима. Треба узети у обзир да су грађани већег дела бивше Југославије од деведесетих година прошлог века формирали ксенофобичну реакцију на људе који не припадају њиховом националном корпусу" ${ }^{4}$ Томе су допринела ратна дешавања, али и медијске конструкције и говор мржње у медијским текстовима чији је циљ био психолошка мобилизација и припрема за предстојећа ратна разрачунавања на простору Балкана.

Ксенофобија, као наслеђе потекло из тог периода, може и данас да се ревитализује и мобилизује у складу са интересима политичке и медијске елите. Многи медији тржишно оријентисани и данас ка ксенофобији, потенцирању стереотипа и предрасуда осмишљавају садржај зарад што веће популарности. То узрокује да се ново и непознато представи као вид претње. Промена медијске екологије и дигитализација медија додатно је угрозила позицију штампе на тржишту. Штампани медији грчевито се боре да опстану у дигиталном

\footnotetext{
${ }^{4}$ Драгомир Пантић наводи да је ксенофобија међу Србима и Хрватима значајно ојачала и достигла свој врхунац током 1993. године. То поткрепљује податком да је ксенофобија била присутна код 76\% становника у мају 1993. године, док је раније, пре одређених дешавања, попут рата у Босни и Херцеговини и Хрватској, санкција УН и економског колапса, била у умереном облику присутна код 10-15\% становништва и у Србији и у Хрватској (Пантић, 1998).
} 
окружењу, а на промене одговарају повезивањем са мрежом и оснивањем сајтова. Међутим, нове платформе комуницирања нису довеле до плурализма садржаја и веће аналитичности у раду с обзиром на већи комуникацијски простор. Напротив, и озбиљнији листови све чешће посежу за таблоидним стилом извештавања.

\section{ЗАКљУЧАК}

Савремено, умрежено друштво почива на медијима, чија моћ данас досеже неслућене границе. Не постоји област друштвеног живота која није посредована медијским каналима, а њихова улога ствараоца стварности и представа према другом постаје још значајнија. Мигрантска криза није заобишла овај део Европе, а управо су медији, како је овај рад показао, имали најзначајнију улогу у конструисању слика о људима који су масовно пролазили кроз Србију. Анализа је показала да је интересовање за ову тему било велико чак 328 текстова у Блииу. С обзиром на то да је реч о релативно далеком народу и култури која је већини становништва била непозната до избијања кризе, страх од непознатог је очекиван. Међутим, медијска мобилизација страха од непознатог, а према потребама и интересима владајућих друштвених кругова, питање је етичке професионалности медија и медијских радника. Наиме, већи део миграната долази из дела света који је у медијском дискурсу годинама негативно заступљен због веза са тероризмом, што доводи до стварања предрасуда, али и страха. Анализа је показала да, и у случају избегавања директне везе између миграната и тероризма, избор текстова их у конотативном смислу ставља управо у тај контекст (Затварање граница, насилни протести и сл.). То показује да су предрасуде већ створене, да су мигранти и избеглице групно хомогенизовани, односно да су осуђени без доказа. Предрасуде и страх од непознатог присутни су и у другом анализираном периоду, када је највећи талас кризе прошао и у коме се највише пажње поклања појединачним случајевима са циљем да се представи због чега се ови људи не уклапају у један културолошки оквир који је, такође, медијски посредован.

Поређењем начина извештавања о мигрантској и избегличкој кризи уочено је да је сензационализам, кроз употребу стереотипних категорија, присутан у таблоидно оријентисаним медијима. Међутим, елементи овакве врсте садржаја, додуше у знатно мањој мери, присутни су и у такозваној озбиљној штампи. Непрестана борба за што бољу позицију на медијском тржишту за резултат је имала медијске продукције. Сурови услови опстанка на тржишту намећу проверени образац преживљавања и борбе са медијском конкуренцијом, која може да се победи једино понудом садржаја привлачних већини читалаца. То је навело и озбиљне, објективне и квалитетне медије на 
промену политике пословања, па су се многи дневни листови окренули сензационалистичкој, таблоидизираној форми извештавања која не води рачуна о квалитету саопштења, нити о чињеницама.

Када је реч о етичкој димензији, највећи проблем представља визуелна представа текстова. Одабране фотографије углавном служе за привлачење посетилаца, а не илустровање текстова. Примери су фотографије у којима је фокус да се што боље прикаже патња миграната, приказивање малолетних особа без дозволе и сл. Једна од главних тема у првом анализираном периоду била је смрт трогодишњег дечака чије је тело пронађено на плажи у Бодруму. Овај пример је кроз преношење детаљних изјава очевидаца, родбине, званичника, извештаја о сахрани, потресних фотографија, показао да сензационализам има примат над етичким стандардима, чак и у оним медијима који се не дефинишу као таблоиди, попут Блица. Сензационализам се додатно наглашава употребом великих слова како би се истакли поједини делови наслова, најчешће изразима попут „Страшно”, „Ужасно”, „Стравично” и сл.

И одабир жанрова код извештавања о овом сложеном феномену показује да су се медији првенствено бавили последицама, а не узроцима. Истраживање је показало да аналитички жанрови, пре свега чланак, нису коришћени у довољној мери, а управо су они најподеснији за извештавање о оваквим догађајима како би се добио детаљнији увид у саму суштину проблема и како би се проблем сагледао из више углова. Доминантност информативних жанрова показује површност у приступу, па конзументи медијских садржаја остају ускраћени за шири контекст приче о мигрантској кризи. Због тога се извештавање о овим људима заснива на већ постојећим представама, што може само допринети учвршћивању стереотипа и негативне перцепције. Чак ни медији чији садржај није таблоидан, попут Политике, не излазе много из унапред утврђених оквира када је реч о представљању Другог. То медијима, као ствараоцима стварности, отвара велике могућности да злоупотребе огромну моћ коју имају.

Медијски оквири сужавају оптику публике усмеравајући њену пажњу и свест у правцу конструисаних верзија истине и стварности произведених у центрима друштвене и политичке моћи. У конвергентном умреженом друштву, традиционалним медијским каналима придружују се и нови медијски путеви који омогућавају окупљање шире публике. Посредством дигиталних канала и сајтова дневних листова централизовани медијски наративи о мигрантској и избегличкој кризи доспевају до најширег могућег аудиторијума. Позивање на критички приступ медијским текстовима сигуран је пут који може да сачува публику од заблуда слепог прихватања медијских оквира као једине могуће верзије истине и друштвене стварности. 


\section{ЛИТЕРАТУРА}

Caviedes, A. (2015). An Emerging European News Portrayal of Immigration. Journal of Ethnic and Migration Studies, 41(6), 897-917. doi: 10.1080/1369183X.2014. 1002199

Cheregi, B. F. (2015). The media construction of anti-immigration position: the discourse on the Romanian immigrants in the british press. Dostupno na: http://revistadesociologie.ro/pdf-uri/NR.3-4-2015/05-BCheregi.pdf

D’Angelo, P. Kuypers, A. J. (2010). Doing News Framing Analysis. New York and London: Routledge.

Džajls, D. (2010). Psihologija medija [Psychology of Media]. Beograd: Clio.

Entman, R. (1993a). Framing toward clarification of a fractured paradigm. Journal of Communication, 43(4), 51-58.

Gamson A. W et al. (1992). Media Images and the Social Construction of Reality, in Annual Review of Sociology, Vol. 18. (1992), pp. 373-393.

Goffman, E. (1974). Frame Analysis. New York: Harper \& Row.

Hall, S. (1977). The work of representation. in Hall, S. (ur.), Representation: Cultural Representations and Signifying Practice. London: Sage and The Open University. pp. 13-75.

Holmes, S. M., \& Castaneda, H. (2016). Representing the European refugee crisis in Germany and beyond: Deservingness and difference, life and death: Representing the European refugee crisis. American Ethnologist, 43(1), 12-24. doi: 10.1111/ amet. 12259

Јевтовић, 3., Петровић, Р. и Арацки, 3. (2014). Жанрови у савременом новинарству [Genres in Contemporary Journalism]. Београд: Јасен

Јевтовић, 3., Бајић, П. (2016). Мигрантска криза у огледалу српске дневне штампе (Migrant crisis in a mirror of Serbian daily press). Култура полиса, часопис за неговање демократске политичке културе, год. XIII, бр. 31, Београд: Култура - Полис Нови Сад и Институт за европске студије, стр. $29-43$.

Јевтовић, 3., Бајић, П. (2017). Промена комуникационе парадигме у извештавању о мигрантима у дневној штампи Србије (Change of communication paradigm in reporting about migrants in Serbian daily press). Култура полиса, год. XIV, посебно издање, стр. 221-239.

Jovanović, Z. (2015). Virtuelna planeta [Virtual Planet]. Niš: Filozofski fakultet.

Livingstone, Sonia (2009). On the Mediation of Everything: ICA Presidential Address 2008. Journal of Communication 59 (1): 1-18. doi:10.1111/j.1460-2466.2008. 01401.x.

Lippmann, Walter (1995) Javno mnijenje (Public Oppinion): Zagreb: Naklada „Naprijed”.

McChesney, Robert W (1999). Rich Media, Poor Democracy: Communication Politics in Dubious Times. University of Illinois Press.

Milivojević, Snježana (2015) Mediji, ideologija i kultura (Media, Ideology and Culture). Beograd: Fabrika knjiga

Pantić, Dragomir (1998): Politička kultura i vrednosti. Fragmenti političke kulture (Fragments of political culture) (grupa autora). Beograd: Institut društvenih nauka, Centar za politikološka istraživanja i javno mnenje, (38-79).

Pavlik, John (2001): Journalism and New Media, New York, Columbia University Press.

Reese, D. S, Gandy, H. O., Grant, E.A. (2008). Framing public life. Taylor \& Francis e-Library.

Stojković, I. Petković, V. (2015). Medijska predstava o prirodnim katastrofama u Srbiji - manipulacija i dezinformacije (Media representation of natural 
disasters in Serbia - manipulation and disinformation), Zbornik radova: Državnost, demokratizacija i kultura mira (Collection of Papers: Statehood, democratization and peace culture), Niš: Univerzitet u Nišu, Filozofski fakultet, 325-339.

Todorović, Neda (2006). Tabloidni žurnalizam (Tabloid journalism). $C M$, Časopis za upravljanje komuniciranjem br. 1, Beograd: Fakultet političkih nauka, 19-30.

Van Gorp, B. (2005). Where is the frame? Victims and intruders in the Belgian press coverage of the asylum issue. European Journal of Communication, 20, 485508.

Van Gorp, B. (2007). The Constructionist Approach to Framing: Bringing Culture Back In. Journal of Communication, Vol. 59, Issue 1, 60-78.

Van Gorp, B. (2010). Strategies to Take Subjectivity Out of Framing Analysis. Doing News Framing Analysis (ed. D'Angelo, P. Kuypers, A. J), New York and London: Routledge, pp. 84-110.

Vuletić, V., Stanojević, D., Vukelić, J., \& Pešić, J. (2016). Studija o izbeglicama Srbija 2016 (Study about refugees - Serbia 2016). Beograd: Friedrich Ebert Stiftung - Centar za primenjena društvena istraživanja. URL: http://library. fes.de/pdf-files/bueros/belgrad/12928.pdf.

\title{
MIGRANT AND REFUGEE CRISIS: COMPARATIVE ANALYSIS OF MEDIA REPORTING - CASE STUDY DAILY NEWSPAPER BLIC, POLITIKA AND KURIR
}

\author{
Dušan Aleksić, Ivana Stamenković \\ University of Niš, Faculty of Philosophy, Department of Communicology and \\ Journalism, Niš, Serbia
}

\begin{abstract}
Summary
Migrant crisis which affects Europe occupies significant media space in which, through using symbols craftily, contents about migrants and refugees are created. Media generated images affect mental models of recipients of messages and help them to devise various political and social occurences. Those images become specially influental when they are reffered to culturally different groups. With an intention to show how chosen news portals in Serbia reported about migrant and refugee crisis, this paper is, above all, focused on analyzing several aspects of journalistic texts: frequency of texts about migrants and refugees, analysis of used genres, titles, visual representation, respecting of journalistc ethics and examination of used rhetorical, stylistic and manipulative agents. Analysis of texts on three news web portals „Blic“, „Kurir“ and „Politika“ published during the twoweek period, from September 1 to September 72015 and from March 1 to March 72017 showed that „Blic“ devoted most texts to migrant crisis - 328. From an aspect of media space devoted to these topics, the smallest part took „Politika“ - only 29 texts. When it comes to journalistic genres, the biggest percentage of texts belongs to strictly informative group - published as news and reports. Those texts are mostly based, explicitly or sometimes implicitly. on existing stereotype frames. The exisisting pattern that represents a trend in reporting about migrant and refugee crisis is also visible in visual representation in which a photography doesn't ilustrate a text, but it has a task to attract as many readers as possible using a so called model of warming hearts stories (suffering, pain etc.). The
\end{abstract}


conclusion of this paper is that violation of ethics standards is not something related to tabloids only, but to media that don't have such characteristics as well - in this case „Politika“, which more and more rely on already tried forms of reporting about Others carrying about number of readers and circulation only. That opens the question of responsibility of media considering that they create social reality and the public is directed towards its presentations. Especially, maybe the largest, part of the public that lacks skills of critical reading of media texts. 